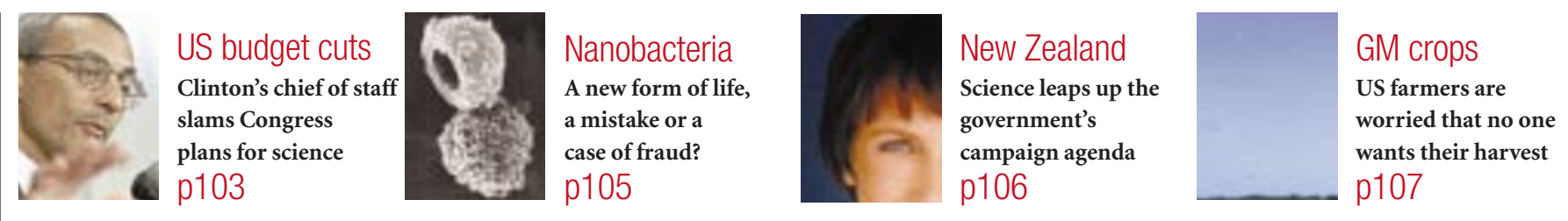

\title{
US energy secretary roasts tardy nuclear weapons laser project
}

\section{Washington}

The National Ignition Facility (NIF), the $\$ 1.5$ billion centrepiece of the US Department of Energy's stewardship programme for the country's nuclear weapons stockpile, is running two years late and hundreds of millions of dollars over budget.

Bill Richardson, the energy secretary, revealed the cost overruns last week, in a blistering statement blaming the Lawrence Liv-

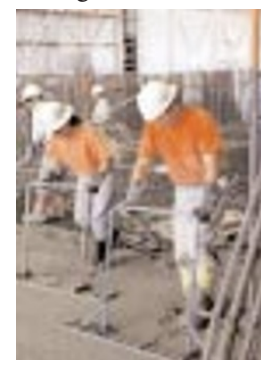

Step on it: project is two years behind. ermore National Laboratory and the University of California, which manages the laboratory for the Department of Energy (DoE), for letting them occur.

Michael Campbell, the Livermore Laboratory's associate director of lasers and the director of the project, resigned on 27 August.

Campbell left after an anonymous tip-off that he had never received his $\mathrm{PhD}$ from Princeton University.

A crisis meeting on 31 August between DoE officials led by Gil Weigand, head of the nuclear weapons research programme, and Livermore Laboratory officials, revealed the extent of the problems, and led to Richardson's announcement on 3 September.

"I am deeply disturbed to learn of projected cost overruns and scheduling delays associated with the National Ignition Facility project," said Richardson. "I am also gravely disappointed with the University of California and the Department of Energy's Lawrence Livermore Laboratory for its late reporting of these significant problems."

Richardson announced a six-step plan to get the project "back on track," starting with an order to the Livermore Laboratory to subcontract out assembly of the NIF's giant laser systems, and the appointment of an outside panel to select "the best technical course of action" for the project.

The Livermore Laboratory issued a statement acknowledging "the importance of project management," but did not endorse Richardson's view that the project is over budget.
Laboratory officials believe that technical uncertainties have always threatened the project's timetable and budget - especially over the need to assemble it all in a cleanroom atmosphere, and the challenge of getting the high-powered lasers to work. Critics of the NIF, led by the Natural Resources Defense Council in Washington, have long claimed that the machine is unlikely to meet its goal of igniting a fusion target.

A senior energy department official said that the NIF didn't face any major technical obstacles, but that the project planning had been mismanaged, and that the Livermore Laboratory would be unable to assemble the huge lasers itself. Giving the job to an outside contractor will prolong it, he said. The NIF would be ready in 2005 instead of 2003, increasing the cost of the project by "hundreds of millions of dollars". The outside panel, he said, would consider options including scaling back the project, reducing the number of lasers from 192 to 96 or delivering an energy of 1.5 megajoules (MJ) instead of the $1.8 \mathrm{MJ}$ originally envisaged.

A source close to the laboratory said there were problems with the high-speed crystallization process used for making key optical elements of the NIF. But the DoE official said he had no knowledge of such problems, and Richardson's statement said "the problems with the NIF are not technological: these are project management issues".

Richardson said that any cost overruns would come out of the Livermore Laboratory's $\$ 1$ billion annual budget, "so that the US taxpayer does not foot additional bills because of these problems". He promised to withhold "at least \$2 million" of the University of California's management fee for running the laboratory, and has asked the laboratory to discipline staff who may have covered up the problems. As recently as June, the laboratory said the project was on time and on budget (see Nature 399, 622;1999).

This is a bad time for the DoE and nuclear weapons laboratories. The department is facing difficulties with its other main scientific project - the Advanced Neutron Spallation Source at Oak Ridge National Laboratory in Tennessee. And the nuclear weapons laboratories, which are usually immune to political opposition, have been attacked for security lapses following Chinese espionage, leading some in Congress to question their $\$ 4$ billion annual budget. Colin Macilwain

\section{Chimp care causes furrowed brows}

\section{San Diego}

The United States' largest chimpanzee research facility has reached a deal with the government to settle a long-running dispute over allegations of substandard care.

The Coulston Foundation, in New Mexico, will reduce the number of chimps it houses by $\mathbf{3 0 0}$ over the next two years. It will bring in an outside review team to examine animal care and increase veterinary services.

A $\$ 100,000$ fine by the US Department of Agriculture (USDA) is being held in abeyance to ensure that the foundation complies with the settlement's consent agreement, under which it admitted no wrongdoing.

Questions remain about where the 300 chimps will go, where the money will come from to pay for their care - the animals may live to the age of 50 - and how they may be used for future research.

Animal rights activists, who prompted the USDA action against the Coulston Foundation, have been pushing for sanctuaries for the research chimps, some of which have infections such as HIV.

Killing surplus chimps has been ruled out by the National Institutes of Health (NIH), which is reviewing proposals for long-term care of primates now kept at Coulston and at other facilities. A decision is expected by next spring.

About \$ 4 million a year is being set aside for their maintenance, but critics question whether that is enough.

Rex Dalton 